\title{
SUBDURAL HEMATOMA WITH SYMPTOMS OF EPILEPTIC ATTACKS AFTER SUBARACHNOIDAL ANESTHESIA - A CASE REPORT
}

\author{
Emilija Ivanov ${ }^{1}$, Dafina Karadzova ${ }^{1}$, Ana Doneva ${ }^{2}$, Jordan Nojkov$^{3}$, Atanas Sivevski $^{1}$
}

\begin{abstract}
The study describes a case of subdural hematoma developed after cesarean section in a 34-year-old patient with normal intra-operative course.

During the first twelve hours after the operation, the patient had a headache considered as post-dural puncture headache (PDPH) and was treated in that direction.

After the third operative day the headache was reduced, and on the fifth day the patient was discharged from the hospital in good condition. As soon as the patient was discharged, the headache appeared again with stronger and persisting intensity and the end it was accompanied by epileptic seizure. MR scan showed subdural hematoma in absorption. After conservative therapy, the condition was improved and the patient was without neurologic consequences. The differences between PDPH and other types of headache, as well as the potential etiopathogenesis of subdural hematoma in obstetric patient, are discussed in this study. We have come to the conclusion that after the long persisting headache, if we take into consideration this complication as a possibility, the early diagnosis and adequate treatment could lead to complete recovery.
\end{abstract}

Acta Medica Medianae 2018;57(4):144-147.

Key words: subdural hematoma, cesarean section, post-dural puncture headache, neuraxial block, subarachnoid anesthesia

${ }^{1}$ University Clinic of Ginecology and Obstetrics, University

"Ss.Cyril and Metodius", Skopje, FYR Macedonia

2General Hospital 8 September, Skopje, FYR Macedonia

${ }^{3}$ Goce Delčev University of Štip, Štip, FYR Macedonia

Contact: Emilija Ivanov

E-mail: ivanovemilija@gmail.com

\section{Introduction}

Spinal anesthesia (SA) is a standard anesthesia for cesarean section both in the world and in the FYR Macedonia. The side effects of this type of anesthesia are headache, sickness, nausea as well as vomiting, bradycardia, hypotension and urinary retention.

The headache after SA is relatively frequent accompanying phenomenon which is usually considered to be the result of dural puncture (PDPH). One should have in mind different diagnoses of headaches of other etiology such as migraine, pains in the temples or frontal pains. However, in everyday work we rarely think of another type of headache as a symptom, except of PDPH due to their infrequent occurrence.
In this study we present a case of post spinal headache, the etiology of which was hemorrhage, i.e., development of subdural hematoma.

\section{Case report}

A 34-year-old female, non-smoker patient who did not consume alcohol. There was no medical history of allergy on food and drugs. Familial anamnesis was negative. The performed routine tests including the number of thrombocytes and coagulation status were within normal limits.

The patient was scheduled for elective cesarean section in the $38^{\text {th }}$ week ( $3^{\text {rd }}$ pregnancy). She underwent elective surgical intervention under spinal anesthesia. Spinal anesthesia was performed at L3L4 using 26G needle. During puncture there was clear liquid, thus Bupivacain $0.5 \% 10 \mathrm{mg}$ and Fentanyl $0.002 \mathrm{mg}$ were administered. The block was performed in a seated position. Blood pressure, pulse, number of respirations and oxygen blood saturation (SpO2) were controlled every five minutes the whole time. Throughout the intervention, the vital parameters were stable and in normal limits. The operation was unremarkable and lasted 40 minutes. During the intervention, the patient was administered $2 \times 500 \mathrm{ml}$ $0.9 \% \mathrm{NaCl}$ and $500 \mathrm{ml}$ Ringer solution. Postoperatively she was administered antibiotic Ceftriaxon $2.0 \mathrm{gr}$, antiemetic Reglan (Metoclopramide) and Ranitidine $2 \times 50$ mg, analgesic Ketoprofen $2 \times 100$ mg, 
Tramadol $2 \times 100 \mathrm{mg}$, low molecular weight heparin (enoxaparin) $0.4 \mathrm{ml}$ (40mg) and uterotonic Ergotyl (methylergometrine maleate) $3 \times 1$. In the period of 24 hours postoperatively, $2000 \mathrm{ml}$ crystalloids were administered intravenously (iv). The patient was recommended to rest 24 hours postoperatively and to take liquids per os after the termination of SA motor block. Anamnestically her past medical history was unremarkable - without previous serious diseases. The patient had two deliveries formerly, both of them performed with cesarean section. Postoperatively, the laboratory results were within normal limits.

Twelve hours after the intervention, there was an onset of a headache, which was considered and treated as post-dural puncture headache (PDPH). Analgesics were administered iv and liquids per os were continued. The headache weakened in a lying position, while it increased while getting up, which led us to the assumption that it was PDPH. The following 48 hours the headache was relieved and as the patient was in good condition she was discharged from the hospital. When she got home the headache was persisting and it did not weaken when the patient was inactive, that is, in a lying position. Since the patient had continuous headache, she went to the Clinic of Neurology where computer tomography was performed. The scan was normal, that is, there were no pathologic substrates. The patient was sent home again, however, she had two epileptic attacks and forty days after the Cesarean section she was hospitalized at the Department of Neurology as an urgent case, due to acute onset seizures (focal motor secondary generalized). During the examination by the physician in attendance, the patient was slightly confused. The neurologic status was as follows: slower reaction of the left pupil of the eye. The remaining cranial nerves were in normal condition. The arms were kept in normal position with discretely pronated right hand, the legs could not be kept all together due to the recent cesarean section. Babinski test showed light reflex asymmetry on the right (positive), the left was negative. MR of the brain was made in standard pulse sequences and planes. Noncontrast TOF angiography of intracranial blood vessels, as well as venography, were additionally performed. Small irregular hypersignal change (residual blood products in chronic resolution), sequela of the previous hematoma, was detected left high parietal cortically.

The following investigation were performed during hospitalization: routine analyses, biochemical analyses, as well as thyroid status, hemostasis factors and urinary status. All the results were within reference values. EEG finding was pathologically changed. EEG with activation methods, unstable, desynchronized basic brain activity, showing degradation and slowing/deceleration during hyperventilation, teta to delta range, as well as separate groups of sharp and slow waves with noticed predilection over the left parietal electrode's. During hospitalization, the patient was treated with anti-edematous therapy corticosteroids, antiepileptic drugs, antibiotic, gastro protection. During hospital stay, the patient was sta- ble, without seizures. The condition was improved with the therapy. After seven days, control MR scan was made which showed that subdural hematoma was completely withdrawn. There was no indication for surgical treatment. The therapy ordinated by the neurologist continued until the control check-up.

\section{Discussion}

Spinal anesthesia is most commonly used for cesarean section both in the world and in the FYR Macedonia. Complications of all types of neuraxial anesthesia are rare, however, they can be very severe. One of the most serious complications of neuraxial anesthesia is the onset of spinal and epidural hematoma. The incidence of these severe complications is really very low, and it is significantly lower in obstetric population than in non-obstetric population. In the study of Rosero and Joshi (1) from 2016, who investigated the complications in more than $3,700,000$ epidural anesthesia (out of which more than 2,300,000 were obstetric epidural analgesia), the incidence was 0.6 per 100,000 cases. On the other side, the onset of intracranial subdural hematoma after neuraxial anesthesia, as it is in our case, is even a more rare complication, and the precise incidence is unknown. Several descriptions of cases have been reported, in obstetric population around 60 , after neuraxial analgesia, but the real number is probably bigger.

The mechanism of subdural hematoma development is considered to be the same as in the development of post-puncture headache (PDPH)(2). During spinal puncture, an opening in the dura is formed, through which cerebrospinal fluid/liquid is coming out, intraspinal and intracranial pressure is decreased, which causes caudal withdrawing of brain structures and tearing of intracranial and subdural veins consequently by which subdural hematoma is developed. Dural gap/hole or fistula may persist up to 18 weeks after the puncture as a result of spinal puncture (3), while the quantity of liquid that is lost can be even greater than $200 \mathrm{ml}$ per day (4), which exceeds the normal production of liquid.

On the other hand, the cerebral subdural hematoma can develop spontaneously in patients in the course of the delivery where anesthesia and dural puncture are not used. The increased intracranial pressure while coughing, Valsalva maneuver, may cause bleeding to which subdural portions of the connecting veins are particularly sensitive (5). Also, it is known that pregnancy increases the risk of brain stroke, and according to certain studies the incidence of brain bleeding is increased in the first 6 weeks after giving birth (6).

Due to the development mechanism, the symptoms that appear in PDPH are similar to those in subdural hematoma. Most frequently, it is the headache which may be accompanied by pain in the neck, nausea, vomiting, photophobia, diplopia, dizziness, as well as eye and hearing problems (7).

The most characteristic is the type of the headache. The headache develops or it worsens on straightening and getting up posture, while it is lost or improved in a lying position being a result of intra- 
cranial hypotension. When subdural hematoma develops, intracranial pressure increases and in one moment the headache can be lost temporarily. It has been described in several cases $(8,9)$, which also happened to our patient. On the fifth day, her headache was very weak and that is why she was discharged from the hospital. Probably, it was the moment when the subdural hematoma developed.

By increasing of intracranial pressure, the postural headache transforms into non-postural and that is actually the main symptom that should give sign that something serious is happening. In the late review of Cuyperset et al. (10) from 2016 who analyzed 56 cases of intracranial subdural hematoma in obstetric population, this symptom which appeared in $83 \%$ of female patients was the most important symptom in differential diagnosis of subdural hematoma. As a result of the increased intracranial pressure, convulsions and other focal neurologic symptoms may appear that point out to serious complications. In our case, there was a transfer from postural to non-postural headache and later on convulsions developed that were a clear indication that something serious was happening. After MR was carried out, the diagnosis was made that it was subdural hematoma.

There are several risk factors that may lead to subdural hematoma development. They are: cerebral atrophy, dehydration, cerebrovascular malformations, multiple punctures, puncture with big needle and use of anticoagulants. Cuyperset et al. (10) presented 56 female patients in their literature review where risk factors were present only in a small number of patients. There are several case reports (11,
12) presenting patients who developed intracranial subdural hematoma after receiving heparin for thromboprophylaxis.

In addition, the description of one case (13) from 2017 shows development of subdural hematoma after long-term consumption of aspirin. One study (14) which investigated the risk for intracranial hemorrhage, demonstrates that long-term consumption of aspirin increases the risk of hemorrhage though the risk is very small. Otherwise, in patients who consume aspirin mortality is higher if hemorrhage develops (15).

In our case, the patient was administered anticoagulant prophylactic therapy the first 7 days postoperatively, the first dose 12 hours after giving birth and afterwards 1 dose in 24 hours. Thus, it is possible that anticoagulant drugs had their role in the development of subdural hematoma.

\section{Conclusion}

Intracranial subdural hematoma as a consequence of neuraxial anesthesia in obstetric patients is very rare, however, it is a particularly serious phenomenon. When a patient complains of strong, persistent headache following regional anesthesia, which is not relieved after the use of conservative measures, the possibility of the existence of subdural hematoma should be considered. Awareness and careful examinations in these cases are obligatory if we want to reach an early diagnosis and adequate treatment before there is irreversible neurologic misfortune or even death.

\section{References}

1. Rosero EB, Joshi GP. Nationwide incidence of serious complications of epidural analgesia in the United States. Acta Anaesthesiol Scand. 2016; 60: 810-20. [CrossRef][PubMed]

2. Macon ME, Armstrong L, Brown EM. Subdural hematoma following spinal anesthesia. Anesthesiology 1990; 72: 380-1. [CrossRef][PubMed]

3. Gass $H$, GoldsteinAS, Ruskin R, Leopold NA. Chronic postmyelogram headache. Arch Neurol 1971;25:16870. [CrossRef][PubMed]

4. Franksson C, Gordth T. Headache after spinal anesthesia and a technique for lessining its frequency. Acta Chir Scand 1946; 94: 443-54. [PubMed]

5. Yamashima T, Friede R L. Why do bridging veins rupture into the virtual subdural space? J Neurol Neurosurg Psychiatry 1984; 47: 121-7. [CrossRef][PubMed]

6. Sharshar T, Lamy C, Mas J L. Incidence and causes of strokes associated with pregnancy and puerperium. Stroke 1995; 26: 930-6. [CrossRef][PubMed]
7. Mokri B. Headaches caused by decreased intracranial pressure: diagnosis and management. Curr Opin Neurol 2003; 16: 319-26. [CrossRef][PubMed]

8. Zeidan A, Farhat $O$, Maaliki $H$, Baraka A. Does postdural puncture headache left untreated lead to subdural hematoma? Case report and review of the literature. Int J Obstet Anesth. 2006; 15: 50-8. [CrossRef][PubMed]

9. Yildirim GB, Colakoglu S, Atakan TY, Büyükkirli H. Intracranial subdural hematoma after spinal anesthesia. Int J Obstet Anesth. 2005; 14: 159-62. [CrossRef][PubMed]

10. Cuypers V, Van de Velde M, Devroe S. Intracranial subdural haematoma following neuraxialanaesthesia in the obstetric population: a literature review with analysis of 56 reported cases. Int J Obstet Anesth. 2016; 25: 58-65. [CrossRef][PubMed]

11. Ortiz M, Aliaga L, Baturell C, Preciado MJ, Aguilar J, Vidal F. Intracranial subdural haematoma-a rare complication after spinal anesthesia. Eur J Anaesth. 1991; 8: 245-8. [PubMed] 
12. Cantais E, Behnamou D, Petit D, Palmier B. Acute subdural hematoma following spinal anesthesia with a very small needle. Anesthesiology. 2000; 93: 1354-5. [CrossRef][PubMed]

13. 13. Yuri Iwase, Manzo Suzuki, Hiroyasu Bito. A case report of intracranial hemorrhage after spinal anesthesia. JA Clin Rep. 2017; 3: 11. [CrossRef][PubMed]

14. García Rodríguez LA, Martín-Pérez M, Hennekens $\mathrm{CH}$, Rothwell PM, Lanas A. Bleeding risk with long-term low-dose aspirin: a systematic review of observational studies. PLoS One. 2016; 11: e0160046.

[CrossRef][PubMed]

15. Saloheimo $P$, Ahonen $M$, Juvela $S$, Pyhtinen J, Savolainen ER, Hillbom M. Regular aspirin-use preceding the onset of primary intracerebral hemorrhage is an independent predictor for death. Stroke. 2006; 37: 129-33. [CrossRef][PubMed]

\title{
SUBDURALNI HEMATOM SA SIMPTOMIMA EPILEPTIČNOG NAPADA NAKON SUBARAHNOIDALNE ANESTEZIJE - PRIKAZ SLUČAJA
}

\author{
Emilija Ivanov ${ }^{1}$, Dafina Karadžova ${ }^{1}$, Ana Doneva², Jordan Nojkov³, Atanas Sivevski ${ }^{1}$ \\ ${ }^{1}$ Univerzitetska Klinika za ginekologiju i akušerstvo Univerziteta Sv. Kiril i Metodije, Skoplje, BJR Makedonija
${ }^{2}$ Opšta Bolnica 8 Septembar, Skoplje, BJR Makedonija \\ 3Univerzitet Goce Delčev, Štip, BJR Makedonija \\ Kontakt: Emilija Ivanov \\ E-mail: ivanovemilija@gmail.com
}

U radu se opisuje slučaj subduralnog hematoma koji se razvio posle carskog reza kod 34-godišnje bolesnice nakon normalnog intraoperativnog toka. Tokom prvih dvanaest časova nakon operacije, kod bolesnice se javila glavobolja za koju se smatralo da predstavlja postduralnu punkcionu glavobolju (PDPH), pa je u tom smislu i tretirana. Nakon trećeg postoperativnog dana, dolazi do slabljenja glavobolje tako da je petog dana otpuštena iz bonice u dobrom opštem stanju. Neposredno nakon otpusta, glavobolja se ponovo javlja, dugotrajnija i jača po intenzitetu, da bi kasnije progredirala u epileptični status. Snimanjem magnetnom rezonancom utvrđeno je postojanje hematoma u apsorpciji. Nakon konzervativne terapije, dolazi do poboljšanja bez pojave neuroloških posledica. U okviru ovog rada razmatrani su razlika između PDPH i glavobolja drugog porekla, kao i etiopatogeneza subduralnog hematoma u opstetriciji. Došlo se do zaključka da u slučaju dugotrajne, perzistirajuće glavobolje treba imati u vidu i subduralni hematom kao komplikaciju, zato što rana dijagnoza i odgovarajuće lečenje vode ka potpunom oporavku.

Acta Medica Medianae 2018;57(4):144-147.

Ključne reči: subduralni hematom, carski rez, postduralna punkciona glavobolja, neuraksijalni blok, subarahnoidalna anestezija 